\title{
Hubungan Konsumsi Sumber Pangan Enhancer dan Inhibitor Zat Besi dengan Kejadian Anemia pada Ibu Hamil
}

\section{Relation of Iron Enhancer and Inhibitor Food Consumption with Anemia in Pregnant Women}

\author{
Rachmahnia Pratiwi*, Dhenok Widari ${ }^{1}$
}

\begin{abstract}
ABSTRAK
Latar belakang: Salah satu zat gizi yang penting bagi ibu hamil adalah zat besi. Penyerapan zat besi dapat ditingkatkan dengan mengkonsumsi sumber pangan enhancer dan mengurangi asupan sumber pangan inhibitor. Terhambatnya penyerapan zat besi meningkatkan risiko anemia yang dapat berakibat buruk bagi kondisi kehamilan dan janin.

Tujuan: Tujuan dari penelitian ini adalah menganalisis kebiasaan konsumsi sumber pangan enhancer dan inhibitor zat besi yang berhubungan dengan kejadian anemia pada ibu hamil.

Metode: Penelitian ini merupakan penelitian observasional analitik dengan desain cross sectional pada 43 ibu hamil trimester III di Kecamatan Pajarakan Kabupaten Probolinggo, sampel diambil dengan metode simple random sampling. Pengumpulan data menggunakan Food Frequency Questionnaire (FFQ) dan pengukuran kadar $\mathrm{Hb}$ menggunakan uji laboratorium menggunakan metode Cyanmethemoglobin, kemudian data di analisis menggunakan uji korelasi spearman.

Hasil: Hasil penelitian menunjukkan rata-rata kadar hemoglobin pada ibu hamil adalah $11,21 \pm 1,07$ $\mathrm{g} / \mathrm{dl}$. Sebagian besar Ibu Hamil Trimester III jarang mengkonsumsi sumber pangan enhancer zat besi $(60,5 \%)$ dan jarang mengkonsumsi inhibitor zat besi $(39,5 \%)$, serta responden yang mengalami anemia juga cukup tinggi (41,9\%). Tidak terdapat hubungan antara kebiasaan konsumsi sumber pangan enhancer zat besi dengan kejadian anemia $(p=0,420)$. Terdapat hubungan cukup kuat antara kebiasaan konsumsi sumber pangan inhibitor zat besi dengan kejadian anemia pada ibu hamil trimester III ( $p=0,005 ; r=0,424)$.

Kesimpulan: Kebiasaan konsumsi sumber pangan inhibitor zat besi berkontribusi terhadap kejadian anemia pada ibu hamil trimester III sehingga ibu disarankan mengurangi konsumsi sumber pangan inhibitor zat besi untuk meminimalisir terjadinya anemia.
\end{abstract}

Kata Kunci: anemia kehamilan, enhancer, inhibitor, zat besi

\section{ABSTRACT}

Background: One of the important nutrients for pregnant women is iron. Iron absorption can be increased by consuming iron enhancers food source and reducing the intake of iron inhibitor food sources. Inhibited iron absorption will lead to anemia and can have adverse effects on pregnancy and fetal conditions.

Objectives: The purpose of this study was to analyzed the consumption habits of iron enhancers and inhibitors food sources associated with the incidence of anemia in pregnant women.

Methods: This research was an observational analytic study with cross sectional design included 43 third trimester pregnant women in Pajarakan Sub-district Probolinggo District, the sample was taken by simple random sampling method. Data were collected using Food Frequency Questionnaire (FFQ) 
and measurement of $\mathrm{Hb}$ level by performing laboratory examination using Cyanmethemoglobin method, then the data analyzed by using spearman correlation test.

Results: The results showed mean of hemoglobin level in pregnant women is $11.21 \pm 1.07 \mathrm{~g} / \mathrm{dl}$. The most of third trimester Pregnant Women rarely consume food source of iron enhancer (60.5\%) and rarely consume food source of iron inhibitor (39.5\%), and respondents who have anemia high enogh (41.9\%). There was no correlation between consumption habits of food source of iron enhancer with the occurrence of anemia $(p=0.420)$. There was strong relation between consumption habit of food source of iron inhibitor with the incidence of anemia in pregnant mother of the third trimester $(p=0.005 ; r=0.424)$.

Conclusion: Food consumption habits of iron inhibitors contribute to the incidence of anemia in third trimester pregnant women so the mother is advised to reduce the consumption of food sources of iron inhibitors to minimize the occurrence of anemia.

Keywords: pregnancy anemia, enhancer, inhibitor, iron

\author{
*Koresponden: \\ rachmahnia@gmail.com \\ ${ }^{1}$ Dinas Kesehatan Kota, Surabaya, Jawa Timur, Indonesia
}

\section{PENDAHULUAN}

World Health Organization (WHO) menyatakan bahwa kejadian anemia pada ibu hamil berkisar antara 20\%-89\% dan menetapkan kadar hemoglobin 11gr/dl sebagai batas normal anemia ${ }^{1}$. Anemia pada ibu hamil merupakan keadaan ibu hamil dengan kadar Hemoglobin $(\mathrm{Hb})$ rendah dengan kondisi kadar hemoglobin dibawah 11 g/dl pada trimester I dan III atau kadar $<10,5$ $\mathrm{g} / \mathrm{dl}$ pada trimester $\|^{2}$. Berdasarkan hasil Riset Kesehatan Dasar (Riskesdas) tahun 2013 prevalensi anemia pada ibu hamil di Indonesia sebesar $37,1 \%^{3}$. Data dari Dinas Kesehatan Provinsi Jawa Timur tahun 2015 menunjukkan bahwa prevalensi anemia pada ibu hamil yaitu sebesar 5,5\%. Prevalensi tersebut tergolong tinggi apabila dibandingkan dengan kejadian kasus maternal lainnya yang ada di Jawa Timur $^{3}$. Pada Kabupaten Probolinggo anemia merupakan kasus maternal paling sering ditemukan pada ibu hamil dengan prevalensi sebesar 8,02\%, hal tersebut akan memberikan dampak tidak baik apabila tidak segera dilakukan tindakan ${ }^{4}$. Bahaya anemia dalam kehamilan dapat mengakibatkan berat badan bayi kurang, plasenta previa (plasenta menempel), eklamsia, dan ketuban pecah dini. Anemia pada masa intranatal dapat mengakibatkan kekurangan tenaga pada saat melahirkan, perdarahan intranatal, serta shock. Pada masa pascanatal dapat terjadi subinvolusi ${ }^{5}$.

Penyebab utama anemia pada ibu hamil umumnya jumlah zat besi yang dikonsumsi tidak sesuai dengan yang dibutuhkan. Kurangnya asupan zat besi akibat dari kurangnya jumlah zat besi yang dikonsumsi, serta pengaruh kemampuan penyerapan zat besi tersebut ${ }^{6}$. Faktor pendorong (enhancer) dan penghambat (inhibitor) menjadi perhatian penting dalam menilai asupan zat besi. Terdapat beberapa zat gizi mikro yang digunakan bersama-sama dengan zat besi untuk meningkatkan penyerapan zat gizi yang disebut dengan faktor pendorong diantaranya vitamin $A$, vitamin $C$, vitamin $B 2$, dan vitamin $\mathrm{B}^{7}$. Namun, terdapat juga beberapa zat dalam makanan yang dapat menjadi penghambat penyerapan zat besi atau inhibitor. Zat tannin dalam teh dan kopi termasuk inhibitor kuat bagi zat besi. Selain itu pada makanan yang mengandung kalsium, fosfat, maupun fitat yang dikonsumsi dalam jumlah besar akan mengganggu penyerapan dari zat besi tersebut ${ }^{8}$. Penelitian sebelumnya yang dilakukan oleh Masthalina, et al (2015) pada remaja putri di Madrasah Aliyah AlAziziyah menyatakan remaja yang mengalami anemia sebanyak $(47,6 \%)$ termasuk kategori sering mengkonsumsi makanan sumber inhibitor zat besi dan sebagian besar $(76,2 \%)$ kadang-kadang mengkonsumsi makanan 
sumber enhancer zat besi. Ada hubungan pola konsumsi faktor inhibitor zat besi dengan status anemia siswi, dan tidak ada hubungan pola konsumsi faktor enhancer Fe dengan status anemia siswi ${ }^{9}$.

Berdasarkan latar belakang tersebut, dapat dipahami peran penting kebiasaan konsumsi ibu hamil dengan kejadian anemia pada ibu hamil. Tujuan penelitian ini adalah menganalisis kebiasaan konsumsi sumber pangan enhancer dan inhibitor zat besi yang berhubungan dengan kejadian anemia pada ibu hamil.

\section{METODE}

Penelitian ini merupakan penelitian observasional analitik dengan desain cross sectional. Tempat pengambilan data adalah puskesmas pembantu di setiap desa di Kecamatan Pajarakan Kabupaten Probolinggo, dengan waktu pengambilan data yaitu bulan Juni - Juli 2018. Populasi penelitian ini adalah ibu hamil Trimester III yang berada di wilayah kerja Puskesmas Pajarakan yang melakukan pemeriksaan dan tercatat oleh bidan desa hingga bulan Juni 2018 yaitu dengan jumlah populasi sebanyak 81 ibu hamil. Kemudian dilakukan pengambilan sampel menggunakan simple random sampling dan dihitung berdasarkan rumus Slovin, sehingga setiap bagian dari populasi memiliki kesempatan yang sama untuk terpilih menjadi sampel. Didapatkan Besar sampel yaitu 43 ibu hamil trimester III, sampel diambil dengan metode simple random sampling.

Variabel yang diteliti adalah kebiasaan makan responden yang meliputi kebiasaan konsumsi sumber pangan enhancer dan inhibitor zat besi. Data kebiasaan konsumsi sumber pangan enhancer dan inhibitor zat besi menggunakan Food Frequency Questionnaire (FFQ) dengan bahan makanan enhancer meliputi daging unggas/ayam, daging sapi, daging kambing, ikan, telur, hati/jeroan, jeruk, tomat, mangga, pepaya, jambu, dan pisang. Sumber bahan makanan inhibitor meliputi tempe, tahu, kacangkacangan, sari kedelai, teh, kopi, susu, dan keju. Bahan pangan tersebut kemudian dikategorikan menurut frekuensi konsumsinya selama satu bulan terakhir yaitu "Sering" apabila mengkonsumsi setiap hari atau $\geq 3 \mathrm{x}$ seminggu, "Jarang" apabila mengkonsumsi $\leq 1 x$ seminggu atau $\leq 3 x$ sebulan, dan "Tidak Pernah". Data status anemia responden diperoleh melalui pengukuran kadar $\mathrm{Hb}$ dengan melakukan pemeriksaan laboratorium menggunakan metode Cyanmethemoglobin. Pengambilan darah dilakukan oleh petugas laboratorium. Dalam penelitian ini sampel darah diambil melalui darah vena bagian dalam fossa cubiti (siku lengan) sebanyak $2 \mathrm{cc}$, kemudian sampel darah yang diperoleh dibawa ke laboratorium Lanostic Probolinggo.

Analisis statistik menggunakan uji korelasi spearman untuk kebiasaan konsumsi sumber pangan enhancer dan inhibitor zat besi responden. Penelitian ini telah mendapatkan persetujuan dari Komisi Etik Fakultas Kesehatan Masyarakat dengan nomor 367-KEPK.

\section{HASIL DAN PEMBAHASAN}

Penelitian dilakukan di Kecamatan Pajarakan merupakan salah satu kecamatan yang terletak di Kabupaten Probolinggo.

Tabel 1. Distribusi Frekuensi Karakteristik Individu Ibu Hamil Trimester III di Kecamatan Pajarakan Kabupaten Probolinggo Tahun 2018

\begin{tabular}{|c|c|c|}
\hline Karakteristik Individu & $n=43$ & $\%$ \\
\hline \multicolumn{3}{|l|}{ Usia (tahun) } \\
\hline Risiko Tinggi $(<20$ dan >35) & 7 & 16,3 \\
\hline Non Risiko Tinggi (20-35) & 36 & 83,7 \\
\hline \multicolumn{3}{|l|}{ Usia Kehamilan } \\
\hline Trimester III Awal (28-31) & 24 & 55,8 \\
\hline Trimester III Tengah (32 - & 11 & 25,6 \\
\hline \multicolumn{3}{|l|}{ 35) } \\
\hline Trimester III Akhir (>36) & 8 & 18,6 \\
\hline \multicolumn{3}{|l|}{ Jarak Kelahiran (Bulan) } \\
\hline$<24$ & 2 & 4,7 \\
\hline$\geq 24$ & 41 & 95,3 \\
\hline \multicolumn{3}{|l|}{ Jumlah paritas } \\
\hline Tinggi (> 2 kali) & 8 & 18,6 \\
\hline Rendah ( $\leq 2$ kali) & 35 & 81,4 \\
\hline \multicolumn{3}{|l|}{ Tingkat Pendidikan } \\
\hline Dasar (SD/SMP/Sederajat) & 25 & 58,1 \\
\hline Menengah & 15 & 34,9 \\
\hline \multicolumn{3}{|l|}{ (SMA/SMK/Sederajat } \\
\hline Tinggi (Minimal D1) & 3 & 7,0 \\
\hline
\end{tabular}


Tabel 2. Distibusi Frekuensi Konsumsi Sumber Pangan Enhancer Zat Besi Ibu Hamil Trimester III di Kecamatan Pajarakan Kabupaten Probolinggo Tahun 2018

\begin{tabular}{lcccccccc}
\hline \multicolumn{1}{c}{$\begin{array}{c}\text { Sumber Bahan Pangan } \\
\text { Enhancer }\end{array}$} & \multicolumn{2}{c}{ Tidak Pernah } & \multicolumn{2}{c}{ Jarang } & \multicolumn{2}{c}{ Sering } & \multicolumn{3}{c}{ Total } \\
\cline { 2 - 9 } & $\mathbf{n}$ & $\mathbf{\%}$ & $\mathbf{n}$ & $\mathbf{\%}$ & $\mathbf{n}$ & $\mathbf{\%}$ & $\mathbf{n}$ & $\%$ \\
\hline Unggas/Ayam & 0 & 0 & 20 & 46,5 & 23 & 53,5 & 43 & 100,0 \\
Daging Sapi & 1 & 2,3 & 34 & 79,1 & 8 & 18,6 & 43 & 100,0 \\
Daging Kambing & 33 & 76,7 & 10 & 23,3 & 0 & 0 & 43 & 100,0 \\
lkan/Seafood & 2 & 4,7 & 7 & 16,3 & 34 & 79,1 & 43 & 100,0 \\
Telur & 1 & 2,3 & 16 & 37,2 & 26 & 60,5 & 43 & 100,0 \\
Jeroan/Hati & 10 & 23,3 & 21 & 48,8 & 12 & 27,9 & 43 & 100,0 \\
Jeruk & 6 & 14,0 & 19 & 44,2 & 18 & 41,9 & 43 & 100,0 \\
Tomat & 5 & 11,6 & 15 & 34,9 & 23 & 53,5 & 43 & 100,0 \\
Mangga & 4 & 9,3 & 22 & 51,2 & 17 & 39,5 & 43 & 100,0 \\
Pepaya & 5 & 11,6 & 22 & 51,2 & 16 & 37,2 & 43 & 100,0 \\
Jambu & 9 & 20,9 & 25 & 58,1 & 9 & 20,9 & 43 & 100,0 \\
Pisang & 2 & 4,7 & 19 & 44,2 & 22 & 51,2 & 43 & 100,0 \\
\hline
\end{tabular}

Tabel 3. Distibusi Frekuensi Konsumsi Sumber Pangan Inhibitor Zat Besi Ibu Hamil Trimester III di Kecamatan Pajarakan Kabupaten Probolinggo Tahun 2018

\begin{tabular}{lcccccccc}
\hline \multirow{2}{*}{$\begin{array}{l}\text { Sumber Bahan Pangan } \\
\text { Inhibitor }\end{array}$} & \multicolumn{2}{c}{ Sering } & \multicolumn{2}{c}{ Jarang } & \multicolumn{2}{c}{ Tidak Pernah } & \multicolumn{2}{c}{ Total } \\
\cline { 2 - 8 } & $\mathbf{n}$ & $\mathbf{\%}$ & $\mathbf{n}$ & $\mathbf{n}$ & $\mathbf{\%}$ & $\mathbf{\%}$ & $\mathbf{n}$ & $\mathbf{\%}$ \\
\hline Tempe & 24 & 55,8 & 19 & 44,2 & 0 & 0 & 43 & 100,0 \\
Tahu & 27 & 62,8 & 14 & 32,6 & 2 & 4,7 & 43 & 100,0 \\
Kacang-Kacangan & 19 & 44,2 & 21 & 48,8 & 3 & 7,0 & 43 & 100,0 \\
Sari Kedelai & 5 & 11,6 & 17 & 39,5 & 21 & 48,8 & 43 & 100,0 \\
Teh & 11 & 25,6 & 24 & 55,8 & 8 & 18,6 & 43 & 100,0 \\
Kopi & 5 & 11,6 & 14 & 32,6 & 24 & 55,8 & 43 & 100,0 \\
Susu & 14 & 32,6 & 13 & 30,2 & 16 & 37,2 & 43 & 100,0 \\
Keju & 3 & 7,0 & 10 & 23,3 & 30 & 6,8 & 43 & 100,0 \\
\hline
\end{tabular}

Sebagian besar masyarakat yang tinggal di daerah ini adalah warga Suku Madura dan mayoritas bekerja sebagai buruh tani. Karakteristik responden penelitian dijelaskan berdasarkan usia, usia kehamilan, jarak kelahiran jumlah paritas dan tingkat pendidikan.

Berdasarkan pada Tabel 1 diketahui bahwa sebagian besar responden berada pada kelompok usia non risiko tinggi yaitu 20-35 tahun (83,7\%). Usia kehamilan pada responden sebagian besar $(55,8 \%)$ berada pada trimester III awal dengan rentang usia kehamilan 28-31 minggu. Wanita hamil cenderung terkena anemia pada trimester III karena pada masa ini janin menimbun cadangan zat besi untuk dirinya sendiri sebagai persediaan bulan pertama setelah ${ }$ ahir ${ }^{10}$. Penelitian ini sejalan dengan penelitian yang dilakukan oleh Liswanti \& Ediana (2016) di Kelurahan Cilamajang Kecamatan Kawalu
Kota Tasikmalaya yang menunjukkan hasil bahwa sebagian besar ibu hamil memiliki usia dengan rentang 26-35 tahun dengan persentase sebanyak $59 \%{ }^{11}$.

Karakteristik responden lainnya adalah jarak kelahiran yang merupakan lama waktu awal kehamilan responden saat ini dengan kelahiran sebelumnya. Distribusi frekuensi jarak kelahiran menunjukkan bahwa sebagian besar responden memliki jarak kelahiran $\geq 24$ bulan atau 2 tahun (95,3\%). Jumlah paritas adalah jumlah persalinan yang pernah dialami oleh responden sebelumnya. Tabel 1 menunjukkan bahwa sebagian besar responden $(81,4 \%)$ memiliki jumlah paritas rendah yaitu kurang dari atau sama dengan dua kali. Jarak kehamilan yang pendek <2 tahun, merupakan salah satu penyebab anemia, karena perlunya tambahan zat besi untuk meningkatkan jumlah sel darah merah janin dan plasenta. Apabila persediaan 
cadangan zat besi sedikit, maka pada kehamilan berikutnya akan menghabiskan persediaan zat besi dalam tubuh dan akan mengakibatkan anemia pada kehamilan berikutnya ${ }^{12}$. Penelitian yang dilakukan oleh Suryanarayana, et al (2015) di Kamataka, India menyatakan bahwa ibu hamil dengan jarak kehamilan <24 bulan lebih banyak yang mengalami anemia yaitu (61.1\%) dengan jarak kelahiran $<12$ bulan dan (68.4\%) dengan jarak kehamilan 12-24 bulan $^{13}$. Demikian pula dengan jumlah paritas, ibu hamil dengan paritas $>3$ kali dapat meningkatkan frekuensi komplikasi pada kehamilan dan persalinan, seperti meningkatkan risiko terjadinya kematian janin didalam kandungan dan pendarahan sebelum dan sesudah melahirkan, dan hal tersebut lebih sering dijumpai pada ibu hamil yang mengalami anemia ${ }^{12}$.

Pada penelitian ini tingkat pendidikan responden dikelompokkan menjadi dasar, menegah dan tinggi. Sebagian besar responden $(58,1 \%)$ berpendidikan dasar meliputi jenjang SD/SMP/Sederajat. Penelitian ini sejalan dengan penelitian yang dilakukan oleh Liswanti \& Ediana yang menunjukkan bahwa responden ibu hamil sebagian besar memiliki pendidikan hingga SD dengan persentase sebesar $47 \%$.

\section{Kebiasaan Konsumsi Pangan Enhancer dan Inhibitor Zat Besi}

Konsumsi makanan harian adalah faktor luar yang berkaitan dengan berlangsungnya absorbsi zat besi dalam tubuh. Absorbsi zat besi dalam tubuh dipengaruhi oleh beberapa faktor interaksi antar zat makanan yang dikonsumsi ${ }^{14}$. Sumber pangan enhancer zat besi merupakan sumber makanan yang akan mempercepat penyerapan zat besi. Tabel 5 menyatakan bahwa Ibu Hamil trimester III di Kecamatan Pajarakan Probolinggo yang memiliki kebiasaan sering dalam mengkonsumsi sumber pangan enhancer zat besi masih cukup rendah. Dalam penelitian ini sumber pangan enhancer yang sering dikonsumsi oleh responden adalah sebagai berikut Ayam (53,5\%), Ikan (79,1\%), Telur $(60,5 \%)$, Tomat $(53,5 \%)$, dan Pisang $(51,2 \%)$. Namun untuk sumber pangan enhancer lainnya masih jarang dikonsumsi bahkan tidak pernah. Pada wanita yang memiliki kebiasaan mengkonsumsi daging merah atau ayam 2 kali atau lebih selama satu minggu sebelum kehamilan cenderung memiliki kadar hemoglobin lebih dari $>11 \mathrm{gr} / \mathrm{dl}^{15}$.

Sumber pangan inhibitor zat besi merupakan sumber makanan yang akan menghambat penyerapan zat besi. Sebagian besar Ibu Hamil Trimester III di Kecamatan Pajarakan Kabupaten Probolinggo yang sering mengkonsumsi sumber pangan inhibitor zat besi seperti yang ditunjukkan pada Tabel 5 . Dalam penelitian ini didapatkan hasil bahwa sebagian besar responden sering mengkonsumsi tempe $(55,8 \%)$ dan tahu $(62,8 \%)$. Sumber bahan makanan yang merupakan inhibitor zat besi yang diteliti pada penelitian ini berasal dari bahan makanan sumber tanin, fitat, dan kalsium ${ }^{16}$.

\section{Status Anemia}

Kejadian anemia adalah suatu keadaan kadar hemoglobin $(\mathrm{Hb})$ lebih rendah daripada nilai normal. Dapat diklasifikasikan menjadi anemia apabila kadar $\mathrm{Hb}<11 \mathrm{~g} / \mathrm{dl}$ dan tidak anemia apabila kadar $\mathrm{Hb}>11 \mathrm{~g} / \mathrm{dl}$. Tabel 4 menunjukkan bahwa masih cukup banyak Ibu Hamil Trimester III di Kecamatan Pajarakan Kabupaten Probolinggo yang mengalami anemia atau kadar hemoglobin $(\mathrm{Hb})<11 \mathrm{~g} / \mathrm{dl}$ sebanyak (41,9\%). Hasil penelitian tersebut juga sejalan dengan penelitian yang dilakukan oleh Liswanti \& Ediana (2016) di Kelurahan Cilamajang Kecamatan Kawalu Kota Tasikmalaya yang menunjukkan bahwa terdapat 23 dari 42 responden ibu hamil yang memiliki kadar nilai $\mathrm{Hb}$ normal dan tidak mengalami anemia.

Tabel 4. Status Anemia dan Kepatuhan Konsumsi Tablet $\mathrm{Fe}$ Ibu Hamil Trimester III di Kecamatan Pajarakan Kabupaten Probolinggo Tahun 2018

\begin{tabular}{lcc}
\hline \multicolumn{1}{c}{ Status Anemia } & $\mathbf{n = 4 3}$ & $\mathbf{\%}$ \\
\hline Anemia & 18 & 41,9 \\
Tidak Anemia & 25 & 58,1 \\
\hline $\begin{array}{l}\text { Kepatuhan Konsumsi } \\
\text { Tablet Fe }\end{array}$ & & \\
Tidak Patuh (<90 & 20 & 46,5 \\
$\begin{array}{l}\text { Tablet) } \\
\text { Patuh ( } \geq 90 \text { Tablet) }\end{array}$ & 23 & 53,5 \\
\hline
\end{tabular}


Penelitian lain yang dilakukan oleh Setyoningsih, et al (2014) di Desa Ulujami Kabupaten Pemalang, menunjukkan bahwa sebagian besar ibu hamil berada pada kategori tidak anemia yaitu sebesar (72,7\%). Penelitian yang dilakukan oleh Setyoningsih, et al (2014) sejalan dengan penelitian yang dilakukan oleh Jose, et al (2016) di Kochi, Kerala, India menyatakan bahwa terdapat ibu $72 \%$ ibu hamil yang mengalami anemia ${ }^{17}$.

Pemerintah memiliki upaya dalam menanggulangi dan mencegah masalah anemia pada ibu hamil salah satunya adalah dengan suplementasi zat besi ${ }^{18}$. Kementrian Kesehatan di India juga merekomendasikan bahwa ibu hamil disarankan untuk mengkonsumsi $100 \mathrm{mg}$ suplementasi besi dan $500 \mathrm{mg}$ asam folat minimal selama 100 hari kehamilan, ibu hamil yang mengkonsumsi suplemen zat besi dan asam folat dapat mengurangi resiko mengalami defisiensi zat besi yang akan menyebabkan anemia ${ }^{19}$. Pada responden penelitian ini memiliki kebiasaan baik dalam mengkonsumsi tablet $\mathrm{Fe}$, yaitu sebagian besar responden (53,5\%) rutin mengkonsumsi tablet Fe setiap harinya. Pada penelitian yang dilakukan oleh Setiawati, et al (2014) di Puskesmas Sekampung Kabupaten Lampung Timur menyatakan bahwa ada hubungan antara asupan Fe dengan kejadian anemia pada ibu hamil, dengan ibu hamil yang kurang mengkonsumsi tablet Fe lebih banyak yang mengalami anemia $(67.3 \%)^{20}$.

\section{Hubungan Kebiasaan Konsumsi Sumber Pangan Enhancer Zat Besi dengan Kejadian Anemia}

Berdasarkan Tabel 5 diketahui bahwa ibu hamil dengan kebiasaan konsumsi sumber pangan enhancer zat besi sering $(66,7 \%)$ dan ibu hamil dengan kebiasaan konsumsi sumber pangan enhancer zat besi jarang $(53,8 \%)$ sebagian besar tidak mengalami anemia. Ibu hamil yang tidak pernah mengkonsumsi sumber pangan enhancer zat besi, memiliki jumlah persentase sama antara yang mengalami anemia dengan yang tidak menagalami anemia . Berdasarkan hasil uji statistik uji statistik dengan rank spearman didapatkan nilai $p$-value $>0,005$ yang artinya tidak terdapat hubungan antara kebiasaan konsumsi enhancer zat besi dengan kejadian anemia pada ibu hamil trimester III di Kecamatan Pajarakan Kabupaten Probolinggo. Hal tersebut disebabkan karena beberapa jenis sumber makanan enhancer hanya dapat bekerja maksimal pada sumber zat besi heme daripada non heme dalam penyerapan zat besi $^{21}$. Seperti halnya dengan vitamin $A$, vitamin $A$ dapat membantu zat besi heme dapat larut di mukosa usus, sehinga zat besi dapat diabsorbsi. Apabila zat besi yang dikonsumsi bukan zat besi heme maka peran vitamin $A$ tidak dapat bekerja dengan maksimal. Sama seperti vitamin A, vitamin C juga membantu penyerapan di usus. Selain itu, vitamin $\mathrm{C}$ menyalurkan besi non heme jika berinteraksi dengan inhibitor zat besi. Sifat reduktor paling kuat terdapat dalam asam askorbat. Efek vitamin B2 dan B6 dalam absorbsi kemungkinan memang tidak sebesar vitamin C. Vitamin B2 dan vitamin B6 juga lebih berkaitan dengan protein dalam sintesis heme ${ }^{22}$.

Hasil penelitian tersebut sejalan dengan penelitian yang dilakukan oleh Masthalina, et al (2015) terkait pola konsumsi faktor inhibitor dan enhancer terhadap status anemia remaja putri yang menunjukkan hasil bahwa tidak terdapat hubungan yang signifikan antara konsumsi sumber makanan enhancer zat besi dengan status anemia pada siswi, yang mana hasil menunjukkan bahwa sebagian besar siswi kadang-kadang mengkonsumsi makanan sumber enhancer yaitu sejumlah $76,2 \%{ }^{9}$.

Penelitian ini tidak sejalan dengan penelitian lain yang dilakukan oleh Marina, et al (2015) pada remaja putri di SMA Negeri 10 Makassar menyatakan bahwa tidak ada hubungan antara asupan protein dengan status hemoglobin pada remaja putri. Terdapat (90,2\%) remaja putri yang mengalami anemia dan memiliki asupan protein cukup, kemudian pada remaja putri dengan status hemoglobin normal dengan asupan protein cukup sebanyak $(92,8 \%)^{23}$.

\section{Hubungan Kebiasaan Konsumsi Sumber Pangan Inhibitor Zat Besi dengan Kejadian Anemia}

Tabel 5 menunjukkan bahwa ibu hamil dengan kebiasaan sering mengkonsumsi 
Tabel 5. Tabulasi Silang Kebiasaan Konsumsi Sumber Pangan Enhancer dan inhibitor Zat Besi menurut Status Anemia Ibu Hamil Trimester III di Kecamatan Pajarakan Kabupaten Probolinggo Tahun 2018

\begin{tabular}{|c|c|c|c|c|c|c|c|c|}
\hline \multirow{3}{*}{$\begin{array}{c}\text { Kebiasaan Konsumsi } \\
\text { Enhancer }\end{array}$} & \multicolumn{4}{|c|}{ Status Anemia } & \multirow{2}{*}{\multicolumn{2}{|c|}{ Total }} & \multirow{3}{*}{$p$-value } & \multirow{3}{*}{$r$} \\
\hline & \multicolumn{2}{|c|}{ Anemia } & \multicolumn{2}{|c|}{ Tidak Anemia } & & & & \\
\hline & $\mathbf{n}$ & $\%$ & $\mathbf{n}$ & $\%$ & $\mathbf{N}$ & $\%$ & & \\
\hline Sering & 5 & 33,3 & 10 & 66,7 & 15 & 100 & & \\
\hline Jarang & 12 & 46,2 & 14 & 53,8 & 26 & 100 & 0,420 & \\
\hline Tidak Pernah & 1 & 50,0 & 1 & 50,0 & 2 & 100 & & \\
\hline
\end{tabular}

Kebiasaan Konsumsi Inhibitor

\begin{tabular}{lcccccccc}
\hline Sering & 10 & 76,9 & 3 & 23,1 & 13 & 100 & & \\
Jarang & 5 & 24,9 & 12 & 70,6 & 17 & 100 & 0,005 & 0,424 \\
Tidak Pernah & 3 & 23,1 & 10 & 76,9 & 13 & 100 & & \\
\hline
\end{tabular}

sumber pangan inhibitor zat besi sebagian besar mengalami anemia (76,9\%). Sedangkan pada ibu hamil yang jarang dan tidak pernah mengkonsumsi sumber pangan inhibitor zat besi sebagian besar mengalami anemia lebih rendah yaitu $24,9 \%$ dan $23,1 \%$.

Hasil analisis menggunakan uji spearman dengan $\alpha=0,05$ didapatkan nilai $p$ value $<0,05$ sehingga $\mathrm{HO}$ ditolak, yang artinya terdapat hubungan antara kebiasaan konsumsi sumber pangan inhibitor zat besi dengan kejadian anemia pada Ibu Hamil Trimester III di Kecamatan Pajarakan Kabupaten Probolinggo. Dengan nilai koefisien korelasi spearman sebesar 0,424, sehingga dapat disimpulkan bahwa kebiasaan konsumsi sumber pangan inhibitor zat besi dengan kejadian anemia berada pada kategori korelasi moderat atau hubungan cukup kuat.

Hal tersebut diketahui bahwa sebagian besar responden mengkonsumsi tahu tempe sebagai lauk hampir setiap harinya, dimana tahu dan tempe yang berbahan dasar kedelai merupakan salah satu bahan makanan yang mengandung fitat dan merupakan zat yang menghambat penyerapan zat besi. Selain itu juga terdapat beberapa responden lainnya yang mengkonsumsi teh setiap hari, teh dan kopi mengandung tannin yang mampu menghambat penyerapan zat besi dari makanan lain.

Hasil penelitian tersebut sejalan dengan penelitian yang dilakukan oleh Masthalina, et al (2015) menunjukkan hasil bahwa terdapat hubungan antara pola konsumsi faktor inhibitor zat besi dengan status anemia pada siswi. Hal tersebut dikarenakan sebagian besar siswi suka mengkonsumsi makanan seperti teh, pisang, dan coklat yang termasuk dalam daftar bahan makanan yang dapat menghambat penyerapan zat besi ${ }^{9}$. Teh dan kopi mengandung tannin yang mampu menghambat penyerapan zat besi dari makanan lain, selain itu pada teh hitam terkandung senyawa polifenol yang apabila teroksidasi akan mengikat mineral seperti zat besi ${ }^{24}$.

Tannin hanya dapat memberikan efek inhibitornya pada zat besi non heme, sedangkan kalsium pada susu dapat memiliki efek menghambat baik pada besi non heme maupun zat besi heme. Meskipun demikian sifat penghambat pada kalsium tidak akan memperlihatkan dampak jika kandungan kalsium hanya $<40 \mathrm{mg}$ atau bahkan $>300 \mathrm{mg}$. Anjuran konsumsi protein sebagai sumber enhancer adalah $>80 \%$ AKG dan $>77 \%$ AKG untuk vitamin $\mathrm{C}$, apabila konsumsi protein kurang berisiko 26 kali lebih besar menderita anemia dan 47 kali lebih besar apabila konsumsi vitamin $C$ kurang ${ }^{21}$.

Pada penelitian lain yang dilakukan oleh Riswanda (2017) di Kabupaten Muara Enim menyatakan bahwa ada hubungan antara asupan Tanin dengan kadar hemoglobin. Semakin besar asupan tanin, maka semakin rendah kadar hemoglobin sehingga memiliki resiko anemia lebih tinggi. Pada penelitian ini terdapat $(47,66 \%)$ responden yang mengalami anemia dengan asupan tanin lebih dari 10,5 gr/hari ${ }^{25}$. 


\section{KESIMPULAN}

Berdasarkan hasil penelitian pada ibu hamil di wilayah kerja Puskesmas Pajarakan Kabupaten Probolinggo tahun 2018 tidak terdapat hubungan antara kebiasaan mengkonsumsi sumber pangan enhancer zat besi dengan kejadian anemia pada ibu hamil. lbu hamil yang sering mengkonsumsi sumber pangan inhibitor zat besi mayoritas mengalami anemia. Terdapat hubungan antara kebiasaan mengkonsumsi sumber pangan inhibitor zat besi dengan kejadian anemia. Peneliti menyarankan agar mengurangi konsumsi sumber pangan inhibitor zat besi untuk mencegah terjadinya anemia minimal konsumsi 1-3 kali dalam seminggu.

\section{ACKNOWLEDGEMENT}

Terima kasih kepada Badan Kesatuan Bangsa dan Politik Provinsi Jawa Timur dan Kabupaten Probolinggo serta Dinas Kesehatan Kabupaten Probolinggo yang telah memberikan izin sehingga dapat membantu terlaksananya serta kelancaran selama penelitian ini berlangsung. Seluruh staf dan dosen Program Studi Gizi Departemen Gizi Kesehatan Universitas Airlangga khususnya dosen pembimbing atas bimbingan, arahan, serta saran yang diberikan.

\section{REFERENSI}

1. Meihartati, T., Widia, L. \& Lestari, D. A. Hubungan Antara Status Gizi Ibu Hamil dengan Kejadian Anemia. J. Darul Azhar 3, 64-70 (2017).

2. Saifuddin, A. B. Pelayanan Kesehatan Maternal dan Neonatal. (Bina Pustaka Sarwono Prawirohardjo, 2009).

3. Badan Penelitian dan Pengembangan Kesehatan. Riset Kesehatan Dasar 2013. Ministry of Health Republic of Indonesia (2013). doi:10.1007/s13398-014-01737.2

4. Sumarmi, S., Puspitasari, N., Handajani, R. \& Wirjatmadi, B. Underweight as a Risk Factor for Iron Depletion and IronDeficient Erythropoiesis among Young Women in Rural Areas of East Java,
Indonesia. Mal J Nutr 22, 219-232 (2016).

5. Manuaba, I. A. C., Manuaba, I. B. G. F. \& Manuaba, I. B. G. Ilmu Kebidanan, Penyakit Kandungan, dan KB untuk Pendidikan Bidan. (ECG, 2010).

6. Pradanti, C. M., M, W. \& K, H. S. Hubungan Asupan Zat Besi (Fe) dan Vitamin C dengan Kadar Hemoglobin pada Siswi Kelas VIII SMP Negeri 3 Brebes. J. Gizi Univ. Muhammadiyah Semarang 4, 24-29 (2015).

7. Marya, R. K. Patofisiologi Mekanisme Terjadinya Penyakit. (Binarupa Aksara, 2013).

8. Sizer, F. S. \& Whitney, E. Nutrition: Concept and Controversies. (Brooks Cole, 2013).

9. Masthalina, H., Laraeni, Y. \& Dahlia, Y. P. Pola Konsumsi (Faktor Inhibitor Dan Enhancer Fe) Terhadap Status Anemia Remaja Putri. Kemas 11, 80-86 (2015).

10. Sinsin, I. Masa Kehamilan dan Persalinan. (Elex Media Komputindo, 2013).

11. Liswanti, Y. \& Ediana, D. Hubungan Pengetahuan , Sikap Dan Perilaku Konsumsi Zat Besi (Fe) pada ibu hamil terhadap kadar $\mathrm{Hb}$ di Kelurahan Cilamajang Kec . Kawalu Kota Tasikmalaya Tahun 2016. J. Kesehat. Bakti Tunas Husada 16, 161-170 (2016).

12. Abrori, Hutagalung, K. \& Marlenywati. Faktor Anemia Ibu Hamil di Puskesmas Putussibau Selatan. J. Vokasi Kesehat. 1, 99-104 (2012).

13. Suryanarayana, R., Santhuram, A. N., Chandrappa, M., Shivajirao, P. \& Rangappa, S. S. Prevalence of anemia among pregnant women in rural population of Kolar district. Int. J. Med. Sci. Public Heal. 5, 454 (2016).

14. Sari, A., Pamungkasari, E. P. \& Dewi, Y. L. R. Hubungan Asupan Fe dengan Kadar Hemoglobin pada Remaja Putri Anemia di SMK 2 Muhammadiyah Sukoharjo dan SMA N 1 Nguter. 6th Res. Colloq. Univ. Muhammadiyah Magelang 385388 (2017).

15. Pundkar, R., Powar, J., Sonar, S. \& Desai, M. Risk Factors for Anemia in 
Pregnancy: A Case Control Study. Walawalkar Int. Med. J. 4, 17-25 (2017).

16. Putri, S. I. \& Sumarmi, S. Perbandiangan Konsumsi Zat Gizi, Status Gizi, dan Kadar Hemoglobin Pengantin Wanita di Wilayah Pantai dan Pertanian Kabupaten Probolinggo. Media Gizi Indones. 9, 72-77 (2013).

17. Jose, S., Antony, S. C. \& Isaac, B. R. Impact of Knowledge, Attitude and Practice on Anemia status among women in coastal Kochi, Kerala. Int. J. Multidiscip. Curr. Res. 4, 295-298 (2016).

18. Tuyu, S. O. Hubungan Perilaku Mengkonsumsi Tablet $\mathrm{Fe}$ dengan Kejadian Anemia pada Ibu Hamil di Puskesmas Amurang Kecamatan Tombasian Kabupaten Minahasa Selatan. GIZIDO 5, 45-49 (2013).

19. Sharma, J. B. \& Shankar, M. Anemia in Pregnancy. Indian J. Med. Res. 23, 253260 (2010).

20. Setiawati, S., Rilyani, Wandini, R., Wardiah, A. \& Aryanti, L. Faktor-Faktor yang Mempengaruhi Kejadian Anemia pada Ibu Hamil di Wilayah Kerja
Puskesmas Sekampung Kabupaten Lampung Timur Tahun 2013. J. Kesehat. Holistik 8, 53-58 (2014).

21. Mangels, R., Messina, V. \& Messina, M. The Dietitian's Guide to Vegetarian Diets, Issue and Application. (Jones and Bartlett Learning, 2011).

22. Webster-Gandy, J., Madden, A. \& Holdsworth, M. Gizi dan Dietetika. (ECG, 2016).

23. Marina, Indriasari, R. \& Jafar, N. Konsumsi Tanin dan Fitat Sebagai Determinan Penyebab Anemia pada Remaja Putri di SMA Negeri 10 Makassar. J. MKMI 50-58 (2015).

24. Alamsyah, P. R. \& Andrias, D. R. Hubungan Kecukupan Zat Gizi dan Konsumsi Makanan Penghambat Zat Besi dengan Kejadian Anemia pada Lansia. Media Gizi Indones. 11, 48-54 (2016).

25. Riswanda, J. Hubungan Asupan Zat Besi dan Inhibitornya sebagai Prediktor Kadar Hemoglobin Ibu Hamil di Kabupaten Muara Enim. J. Biota 3, 8389 (2017). 